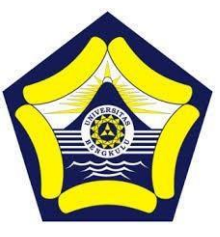

JOLL 4 (2) (2021)

Journal of Lifelong Learning

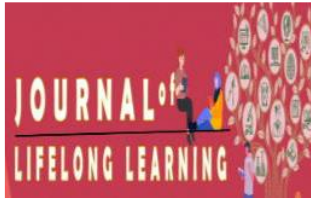

\title{
Pembelajaran Nonformal Santri di Era Pendemic Covid -19
}

\author{
Wandi S ${ }^{1}$, Rufran Zulkaranain ${ }^{2}$ \\ Pendidikan Nonformal Universitas Bengkulu \\ saputrawandig3@gmail.com,rufranzulkarnain@unib.ac.id
}

\begin{abstract}
Abstrak
Penelitian ini bertujuan untuk mendapatkan informasi secara sistematis berkaitan dengan pembelajaran non formal santri di era pandemi covid-19, melalui program-program kegiatan pendidikan non formal yang ada di pondok pesantren Al Hasanah Bengkulu tengah selama pandemi covid-19. Metode yang digunakan adalah Focus grup discusion dengan mendapatkan hasil bahwa pembelajaran non formal santri pondok pesantren di era pandemi covid-19 tetap dapat dilaksanakan pembelajaran dan pelatihan secara tatap muka, yakni dengan menerapkan protokol kesehatan yang ketat, pembelajaran Non formal yang dilaksanakan adalah pelatihan ceramah Agama atau Muhadoroh dengan menggunakan 3 bahasa yakni Arab, Inggris dan Indonesia, selain itu di pesantren Al Hasanah ini wajib menggunakan bahasa Arab dalam setiap berkomunikasinya. Program penghafalan Qur'an pada TPQ yang ada menggunakan metode yang berbeda dari pondok pesantren yang lain yakni dengan menggunakan Metode Qiro'ati yaitu metode pembelajarn Qur'an dengan berlevel level tingkatan mulai dari Jilid 1, Jilid 2. Jilid 3, Jilid 4, dan Gharid. Dimana metode ini bukan berdasarkan lamanya waktu untuk dapat naik level, tetapi berdasarkan kemampuan dari santri itu sendiri dalam menangkap pembelajaran untuk dapat naik level dan dengan diajarkan oleh guru yang sudah mahir di bidangnya yakni yang sudah memenuhi sertifikat Sahada yang dapat mengajarkan Al Qur'an.
\end{abstract}

Kata Kunci: Pembelajaran, Non Formal, Santri, Pandemi Covid-19

\section{Abstract}

The purpose of this study was to determine the pattern of caring for students at the Al Hasanah Bengkulu Tengah Islamic boarding school in the era of the Covid-19 pandemic. This research is a qualitative research with five research subjects and data collection techniques using interview techniques, observation and documentation. While data analysis techniques include data reduction, data presentation, and drawing conclusions. Checking the validity of the data used triangulation starting from time triangulation, subject triangulation and technical triangulation. The results showed that the pattern of caring for students at the Al Hasanah Islamic boarding school in Central Bengkulu in the era of the Covid-19 pandemic was still actively implemented using strict health protocols and the programs owned at the Al Hasanah Islamic boarding school were different from those in other Islamic boarding schools in Indonesia. Central Bengkulu. This Islamic boarding school remains active in carrying out activities even though in the era of the Covid-19 pandemic, in every communication, students are required to use Arabic.

Keywords: Parenting Patterns, Islamic Boarding Schools, Covid-19 Pandemic 


\section{PENDAHULUAN}

Pembelajaran muncul karena adanya suatu kondisi dimana dorongan dari peserta didik untuk meningkatkan ilmu pengetahuan, skill dan kemampuan yang dimilki untuk dapat menjalankan kehidupan yang lebih baik dari sebelumnya baik dari wawasan maupun skill dan kemampuan yang dimilki.

Pembelajaran adalah sebuah kondisi dimana seseorang memperolah pengalaman dan ilmu pengetahuan yang baru baik dari guru maupun lingkungan di sekitarnya guna untuk meningkatkan kualitas dan kapasitas yang ada di dalam diri seseorang.

Definisi pembelajaran adalah proses interaksi peserta didik dengan pendidik dan sumber belajar pada suatu lingkungan belajar. Pembelajaran merupakan bantuan yang diberikan pendidik agar dapat terjadi proses pemerolehan ilmu dan pengetahuan, penguasaan kemahiran dan tabiat, serta pembentukan sikap dan kepercayaan pada peserta didik (Wikipedia)

Pendidikan Non Formal adalah setiap kegiatan yang terorganisasi dan sistematis diluar sistem persekolahan yang mapan, dilakukan secara mandiri atau merupakan bagian penting dari kegiatan yang lebih luas, yang sengaja dilakukan untuk melayni peserta didik tertentu didalam mencapai tujuan belajaranya (Coombs, dalam sudjana, 2000:23)

Pendidikan Non Formal adalah jalur pendidikan diluar pendidikan formal yang dapat dilaksanakan secara terstruktur dan berjenjang. Pendidikan non formal diselenggarakan bagi warga masyarakat yang memerlukan layanan pendidikan yang diperlukan sebagai pengganti, penambah, dan pelengkap, pendidikan formal dalam fungsi mendukung pendidikan sepanjang hayat. (Undang-Undang No 20 tahun 2003)

Santri merupakan peserta didik yang belajar atau menuntut ilmu pengetahuan di dalam pondok pesantren. Banyaknya jumlah santri menjadi tolok ukur sejauh mana pesantren tersebut telah bertumbuh dan berkembang. Manfred ziamek mengklasifikasikan istilah santri ini kedalam dua kategori yaitu santri mukim yaitu santri yang bertempat tinggal di dalam pondok pesantren dan santri kalong yaitu santri yang bertempat tinggal diluar pesantren yang mengunjungi pesantren secara teratur untuk belajar agama.

Pandemi Covid-19 adalah peristiwa menyebarnya penyakit korona virus 2019 bahasa Inggris: Coronavirus disease 2019, singkatan dari covid-19 diseluruh dunia. Penyakit ini disebabkan oleh corona virus jenis baru yang diberikan nama sars-cov-2. Wabah pandemi Covid-19 pertama kali dideteksi di kota Wuhan, provinsi Hubei tiongkok pada tanggal 1 Desember 2019, dan ditetapkan sebagai pandemi oleh organisasi kesehatan dunia (who) pada tanggal 11 Maret 2020. Hinga 17 september 2020 lebig dari 29.864.555 orang kasus positif, telah dilaporkan lebih dari 210 negara dan wilayah seluruh dunia, mengakibatkan lebih dari 940.651 orang meninggal dunia dan lebih dari 20.317.519 orang sembuh. (Wikipedia).

Untuk melakukan program pendidikan non formal di era pandemi covid-19 harus diterapkan protokol covid-19 yang ketat guna untuk menjaga keamanan dan kesehtan dari peserta didik selama melakukan pembelajarn non formal di era pandemi covid-19.

Kegiatan pengasuhan atau program kegiatan di luar kelas Pondok pesantren Alhasanah diantaranya 
adalah sholat berjamaah yang disiplin meskipun di era pandemi covid-19 dan tetap memperhatikan protokol kesehatan dengan menggunakan masker dan menjaga jarak. Selain itu terdapat juga kegiatan Muhadoroh atau pidato santri yang menggunakan 3 bahasa yaitu Bahasa Arab, Bahasa Inggris dan Bahasa Indonesia yang terjadwal secara rutin setiap malam minggu. Kegiatan tersebut juga menjalankan protokol kesehatan seperti menjaga jarak duduk dan menggunakan masker.

Kegiatan lainnya yang terdapat di Pondok Pesantren Al Hasanah yaitu Kelompok Tahfidz Qur'an Santri (KTQ) yang merupkan sekelompok santri pilihan yang menjalankan program hafalan Al Qur'an secara intensif. Pondok Pesantren Al Hasanah memiliki program pembelajaran $\mathrm{Al}$ Qur'an yang memiliki ciri khas yaitu dengan menggunakan metode Qiro'ati. Pembelajaran Alqur'an santri dengan menggunakan metode asistensi Qiro'ati yaitu pembelajaran Alqur'an yang memilki level-level pada setiap kelmpok dan dibimbing dengan guru yang sudah syahada atau sudah memiliki kompetensi khusus untuk mengajar. Di provinsi Bengkulu hanya Pondok Pesantren Al Hasanah yang menggunakan metode tersebut.

Program lainnya yang terdapat di Pondok Pesantren Al Hasanah adalah pola perbaikan bahasa Arab dan Bahasa Inggris seluruh santri. Setiap santri wajib menggunakan Bahasa Arab atau Bahasa Inggris setiap berkomunikasi dan akan mendapatkan sanksi jika tidak menggunakan bahasa tersebut. Di kabupaten Berngkulu Tengah hanya Pondok pesantren Al Hasanah yang mewajibkan santrinya untuk memakai bahasa Arab sedangkan di pesantren lain hanya di anjurkan saja. Selain kegiatan-kegiatan tersebut, Pondok Pesantren Al Hasanah juga tetap menjalankan kegiatan halaqoh mingguan dan aktifitas olahraga setiap sore di masa pandemi covid-19. Di pesantren $\mathrm{Al}$ Hasanah ini memilki banyak program dibidang pendidikan non formal yakni pola asuh yang baik dan berbeda dari pondok pesantren lain sehingga membuat yayasan di pondok pesantren ini maju.

Dari data yang dipaparkan diatas, dapat disimpulkan bahwa meskipun di era pandemi covid-19 program pendidikan non formal tatap muka dapat dilaksanakan dengan syarat dengan menerapkan protokol kesehatan yang ketat, oleh karena itu peneliti tertarik untuk melakukan penelitian tentang "Pembelajaran Nonformal Santri di era pandemi covid-19"

\section{METODE}

1. Pengertian FGD (Focus Grup Discussion)

Metode yang digunakan yakni Focus Grub Disscusion digunakan sebagai cara untuk mengumpulkan data dan Informasi dalam penelitian ini. Pengambilan data kualitatif melalui FGD sangat membeikan peluang dalam mencapai validitas data, karena lebih memberikan peluang dan keterbukaan responden serta menjalin keterbukaan dan kepercayaan responden dalam memahami persepsi setiap responden.

FGD Secara sederhana dapat didefinisikan sebagai suatu diskusi yang dilakukan secara sistematis dan terarah mengenai suatu isu atau masalah tertentu. Irwanto (2006: 1-2) mendefinisikan FGD adalah suatu proses pengumpulan data da informasi yang sistematis mengenai suatu permasalahan tertentu yang sangat spesifik melalui diskusi kelompok.

Sedangkan Irwanto (2006) mendefinisikan FGD sebagai suatu proses pengumpulan data dan informasi yang sistematis mengenai suatu permasalahan 
tertentu yang sangat yang sangat spesifik melalui diskusi kelompok.

Sebagai sebuah metode penelitian maka FGD adalah upaya yang sistematis dalam pengumpulan data dan informasi. Terdapat tiga kunci dalam FGD yaitu sebgai berikut.

1. Diskusi-bukan wawancara atau obrolan

2. Kelompok-bukan individual

3. Terfokus-bukan bebas

Dalam penelitian ini peneliti menggunakan Focus Grup Discussion (FGD) untuk mengetahui pembelajaran non formal santri di era pandemi covid19. Agar data dan Informasi yang diperoleh lebih rinci, sistematis dan terfokus melalui diskusi kelompok.

2. Tujuan FGD (Focus Grub Discussion)

Tujuan FGD adalah untuk mengeksplorasi masalah yang spesifik, yang berkaitan dengan topic yang dibahas. Tekhnik ini digunakan dengan tujuan untuk menghindari pemaknaan yang salah dari peneliti terhadap masalah yang diteliti. FGD digunakan untuk menarik kesimpulan terhadap makna-makna intersubjektif yang sulit diberi makna sendiri oleh peneliti karena dihalangi oleh dorongan subjektifitas peneliti (Kresno dkk. 1999).

Adapun jumlah peserta FGD adalah 5 (lima) orang dalam penelitian FGD digunakan untuk mengetahui pembelajaran non formal santri di era pandemi covid-19 yang dilakukan penelitian pada pondok pesantren AL Hasanah desa talang pauh kabupaten Bengkulu Tengah.

\section{A. Tempat Penelitian}

Penelitian ini dilakukan di pondok pesantren Al Hasanah yang ber alamat di desa talang pauh kecamatan pondok kelapa, kabupaten Bengkulu Tengah provinsi Bengkulu.

\section{HASIL DAN PEMBAHASAN}

A. Persiapan dan Desain Rancangan FGD

1. Membentuk Tim FGD umumnya mencakup:
- Moderator: Ustadz Sudiroh

- Pencatat proses/Notulen: Ahmad Revanza

- Dokumentasi: Ustadz Joko

- Penyedia Logistic: Muhammad Hafidzh

2. Memilih dan mengatur Tempat Di lokasi Pondok Pesantren Al Hasanah desa Talang Pauh, kecamatan pondok kelapa, kabupaten Bengkulu Tengah Provinsi Bengkulu.

3. Jumlah Peserta 8 orang biar bisa fokus

B. Menyusun pertanyaan FGD Penyusunan Pertanyaan-pertanyaan/Guideline Pada FGD dilakukan dengan melihat beberapa hal berikut ini:

- Tujuan penelitian FGD

- Tujuan diadakanya FGD

- Memahami jenis informasi seperti apa jenis informasi yang ingin di dapatkan dari FGD

- Menyusun dari pertanyaan umum ke pertanyaan khusus.

1. Bagaimana pelaksanaan pembelajaran Non Formal santri di era pandemi covid-19?

2. Pembelajaran Non Formal apa saja yang dilaksanakan di pondok pessantren Al Hasanah selama masa Pandemi Covid-19?

3. Bagaimana penerapan protokol kesehatan dalam proses pembelajaran Non Formal santri di era pandemi covid-19?

4. Siapa saja orang-orang yang terlibat dalam kegiatan pembelajaran non formal santri pondok pesantren $\mathrm{Al}$ Hasanah di era pandemi Covid-19?

\section{Pelaksanaan FGD}

a. Menjelaskan maksud dan tujuan FGD, moderator menjelaskan secara detail maksud dan tujuan 
dari FGD hanya untuk kepentingan penelitian dan data dijaga kerahasiaanya dan tidak akan di publikasikan keluar.

b. Menjelaskan topik/isu pokok diskusi

c. Menjelaskan tata cara pelaksanaan dalam FGD.

d. Menciptakan suasana kondusif.

e. Mengelolah dinamika kelompok.

Dari hasil metode FGD mendapatkan informasi bahwa meskipun di era pandemi covid-19 tetap bisa melaksanakan pembelajaran Nonformal dengan cara menerapkan disiplin protokol kesehatan yang ketat yakni memakai masker dan menjaga jarak, menerapkan pemisahan santri antara yang sakit dan yang sehat dimana santri yang sakit dimasukan kedalam ruangan khusus.

\section{KESIMPULAN}

Pandemi Covid-19 sangat mengganggu dan sangat berbahaya sekali untuk dunia pendidikan khususnya dunia pendidikan non formal bagi para santri yang harus tinggal di asrama dalam jangka waktu yang lama dan harus berinteraksi dengan banyk orang setiap harinya, tentunya ini menjadi tantangan bagi setiap elemen yang ada dalam pondok pesantren untuk bisa melaksanakan program di era pandemi covid-19bdengan tetap aman, pondok pesantren $\mathrm{Al}$ Hasanah dalam melaksanakan programnya di era pandemi covid-19 sangat menerapkan protokol kesehatan yang ketat yakni memakai masker dan menjaga jarak, terlebih lagi melakukan pendatangan santri secara berkala yakni 100 santri dan di isolasi terlebih dahulu selama 2 minggu, dan juga dalam menerapkan protokol kesehatan memisahkan antara santri yang sakit dari santri yang sehat dan dilakukan isolasi terlebih dahulu guna untuk mengantisipasi penyebarn pandemi covid-19 selama pembelajaran berlangsung.

\section{DAFTAR PUSTAKA}

Afiyanti, Y. (2008, Maret). FOCUS GRUB DISCUSSION (DISKUSI KELOMPOK TERFOKUS) sebagai metode pengumpulan data penelitian kualitatif. Jurnal keperawatan Indonesia, Vol 12 No 1

Joesoef Soelaiman. 1999. Konsep Dasar Pendidikan Luar Sekolah. Jakarta: Bumi Aksara

Sudjana, D. 20oo. Penddikan luar sekolah, wawasan, sejarah perkembangan, falsafah, teori pendukung, asas. Bandung: Falah Production

Sudjana. 2004. Manajemen Program Pendidikan Untuk Program Pendidikan Non Formal dan Pengembangan Sumber Daya Manusia. Bandung. Falah Production Segara Nyoman yoga. 2017. Etika Dalam Pendidikan Formal, Informal, Dan Non Formal. Denpasar. Jaya Pangus Kamil Mustofa. 2011, Pendidikan Non Formal, Bandung: Alfabeta

Kresno S, Ella Nurlaela $H$. Endah Wuryaningsih, Iwan Ariawa. 1999. Aplikasi Penelitian kualitatif dalam Pencegahan dan Pemberantasan Penyakit Menular, Fakultas Kesehatan Masyarakat Universitas Indonesia bekerja sama dengan Direktorat Jendral Pemberantasan Penyakit Menular dan Penyehatan Lingkungan Pemukiman Depkes RI. Jakarta. 